\title{
COMPANIES INVESTING IN REAL ESTATE LEASING OR RENTAL (FINN) AS POLAND'S REIT - THE CONCEPT OF INSTITUTIONAL CHANGE
}

\author{
Renata Papiė̇
}

\section{Summary}

The planned incorporation into the Polish legal system in the near future and, consequently, the introduction of Companies Investing in Real Estate Leasing or Rental (FINN) into the Polish capital market will result in an institutional change within the financial system. Similarly to closed-ended investment funds and real estate joint-stock companies, the FINN companies will specialize in investing capital in the residential real estate market, and later perhaps also in the commercial real estate market. The principles of FINN's activities included in the legislative draft are modelled directly on the legal regime of the Real Estate Investment Trust (REIT), therefore, they will be subject to numerous prohibitions and limitations, introducing organizational controls and restrictions to the investments, which however is rationally justified. These procedures aim at creating an entity with a structure of a relatively neutral, passive real estate broker or intermediary, focused solely on generating benefits for investors-shareholders.

The initiation of the FINN market in Poland, and thus the scale of the ensuing institutional change, will be determined by the inclination of joint stock companies from the WIGNieruchomości index (Warsaw Stock Exchange Real Estate Index) to transform into FINN companies. In turn, this inclination will be determined by the conditions of institutional change - mostly of a legislative and market-driven character. With this in mind, the aim of this study is to conduct a preliminary analysis of the conditions of institutional change and present a forecast of the development potential of the WIG-Nieruchomości companies, which, due to their very similar scope and form of activity, constitute the main functional basis for the emergence of the FINN market as a new, separate segment of the capital market in Poland.

\section{Keywords}

Company Investing in Real Estate Leasing • FINN • REIT • institutional economics • institutional change $\bullet$ JEL codes: O16, P25, R3

\section{Introduction}

Currently, on the regulated financial real estate market in Poland, only the following entities function as passive intermediaries: closed-ended property investment funds and public joint-stock companies included in the sectoral WIG-Nieruchomości index 
(Warsaw Stock Exchange Real Estate Index). These entities most often apply the structure of special-purpose entities, through which they invest in a selected investment project with a one-time value of several million to several hundred million Polish zlotys. Soon, it will be possible to establish a new kind of a legal entity, which in the legislative draft has been named, literally, the "Company Investing in Real Estate Leasing or Rental” (in Polish, Firma Inwestująca w Najem Nieruchomości, hereinafter: FINN). Just like closed-ended funds and joint stock companies, FINN will specialize in investing capital in the real estate property market, initially only in residential real estate, and in the future probably also in commercial real estate. The activities of FINN, modelled on the Real Estate Investment Trust (hereinafter: REIT), will be burdened with many prohibitions and limits, constraining the investment and economic freedom - unlike the previously mentioned funds and companies. This is intended to create an entity with the characteristics of a relatively neutral, passive real estate broker, focused solely on generating benefits for investors-shareholders. The introduction of FINN to the legal system, and consequently to the Polish capital market, leads us to the formulation of a hypothesis that this will result in a significant institutional change in the Polish financial system. Probably, the scale of this change in the first years after introducing the new legislation will be determined by the declarative, and then the actual inclination of joint stock companies from the WIG-Nieruchomości index to transform into FINN. This tendency will be determined by the conditions of the future institutional change, mainly of a legislative and market-driven nature. The perspective of the aforementioned changes has become the motive for the preparation of the present study, in which our objective is to make a preliminary assessment of the conditions of the proposed legislative changes using the method of institutional analysis. Moreover, we have assumed that - due to the very similar scope and form of activity - the WIG-Nieruchomości companies are going to become the basic functional base for the emergence of the FINN market as a new segment of the capital market. The trend analysis method was used to prepare a forecast for the development of the real estate companies market, leading us to suppose that the dynamics of its development will influence positive decisions on the transformations into FINN and their imminent appearance on the Polish market.

\section{Institutional change}

The concept of institutional change derives from the contemporary trend of the New Institutional Economy (hereinafter: NEI), which appreciates the importance of institutions in the social management process and values the importance of the relationship between the institutional structure and human economic behaviour. D.C. North defined institutions as the set of rules and regulations that limit human behaviour thereby creating the canon upon which the NEI is typically based [North 1990, p. 3-5]. Informal institutions include, for example, codes of behaviour, cultural patterns, as well as various manifestations of social capital, such as trust or networking. On the other hand, formal institutions include the following laws: various forms of property rights, 
financial law, tax regulations, forms of contracts, but also electoral law. By strengthening the rules of the game, institutions determine the structure of stimuli in the process of economic, political or social exchange. In D.C. North's view, there is a visible difference between an institution and an organization - the two concepts that hitherto have been used interchangeably. In practice, organizations are rather bodies of institutional functioning - that is, forms of collective actions of individuality to achieve common goals. Organizations as structures of institutions (for instance, stock exchanges, financial intermediaries, financial market supervision authorities, or political parties) - apart from and in addition to formal and informal institutions - constitute an institutional system in the scale of a given market.

Competition is an inevitable result of constant interaction between institutions and organizations in the conditions of scarcity - and so, as a consequence, competition triggers institutional change, which means the need to introduce new legislative solutions incorporated into new organizations, as it will be in the case of the constitution and subsequent evolution of FINNs. D.C. North indicated five premises for institutional change, where the interaction between institutions and organizations is the first and the most fundamental premise [North 1993]. Then, competition will force organizations to continuously invest in the skills and knowledge of their employees - in order to survive. The nature of the skills and knowledge acquired by employees, and thus also by the organization, will shape the ever-evolving perception of its market opportunities and hence the choices made will gradually be equivalent to those of institutions. As the third premise of institutional change, D.C. North points to the institutional framework, which is the incentive determining the types of skills and knowledge necessary to achieve the maximum benefit from the presence in the market. Another aspect has a cultural dimension, meaning that the way the organization perceives its own status as a market player (aggressive or passive status) is a derivative of the mental structure of that organization. The last, fifth premise is the identification of the complementarity of many factors - such as, for instance, the benefits of scope, the network of individual connections, etc. - as making the institutional change always favourable because it signifies growth, but also it is qualitatively dependent on the chosen path.

The planned incorporation of FINNs into the Polish financial system - analysed on the basis of the above premises of D.C. North - was initiated by competition, especially from foreign entities investing in the commercial real estate market. In the light of the assumptions of NEI, this stimulus will contribute to the creation of a new organization, which, as an entity previously unknown to the Polish market, will perform the functions of a passive investment broker or intermediary in the financial real estate market. It is mainly the knowledge and skills of FINN employees (but also of the immediate environment) that will determine the correct implementation of the legal regime, and thus the effectiveness of operations and the possibility of using competitive advantage. The specificity of the principles of FINNs' operation will certainly contribute to the creation of an organization culture that is particular to them, but at this point it is impossible to predict the way in which the complementarity of factors appearing during the implementation of the development path of these entities will be identified. 
NEI only suggests that their role will certainly be significant in the successful development of the FINN market.

\section{Objectives and principles of the REIT legal regime as a model for FINN}

The origins of REIT go back to the 1940s in the United States, when on the wave of legislative changes an initiative was taken to regulate the status of investors in the real estate market, especially those with different financial capacities. However, the first legal regime for REITs was only included in An Act to Amend the Internal Revenue Code with Respect to the Excise Tax on Cigars signed by President D.D. Eisenhover, as late as 14 September 1960. Since then, the dynamic evolution of REITs has continued, both in the United States, and - on the wave of the globalization process - throughout the world. Nowadays, REIT is a globally recognizable, locally regulated form of investment brokerage that connects the real estate market and the capital market, hence identifying it with the term: real estate financial market entity. Detailed rules of operation and legal forms of REITs in individual countries are very diverse and, as a result, it is difficult to clearly define this category, making it necessary to explain it descriptively. As a rule, it is an institutionalized form of a passive real estate investment broker or intermediary whose activities can be defined from two points of view:

- REIT as a collective investment institution allows a single investor to overcome the barrier of accessibility of high-value investments and to diversify the investment risk on the real estate market.

- REITs make it possible to collect a high-value pool of cash from investors, which is a source of financing for the process of implementing real estate investment projects, selected based on the assumed strategy.

As a legal entity, REITs are unique. This is an example of a passive investment intermediary in the real estate market with a very diverse organizational and legal structure. Around the world, REITs exist in three basic legal forms: trust, joint stock company, and investment fund.

In functional terms, the operations of a REIT consist of long-term direct or indirect investment in real estate, known as eligible activity. The scope of eligible activities in each legal system is always strictly limited and constrained by the acts of law, which is aimed at maintaining the transparency of investment intermediation, i.e. activities on behalf of and for the benefit of the investor - the eligible beneficiary. At the same time, this means excluding the free, unauthorized activity of REITs on their own account, which could include, for example, real estate trading. The set of rules, based on which the REIT operates, legally takes the form of restrictive legislation - the so-called legal regime, the detailed standards of which tend to differ in individual countries where REITs operate. However, a common, key principle of legal regimes is the exemption of REITs from tax liability at the level of the legal entity, in relation to income derived from qualified activities and the simultaneous obligation to regularly distribute these amounts among the investors. Only they, as shareholders (or stockholders), subject 
to individual tax liability, bear the tax burden on account of their capital gains. From the investor's point of view, the use of such a solution is highly beneficial because it increases the profitability of his investment - in which the main source of profit is the income paid by the REIT (dividend) and the possible market change in the value of shares (if the entity is listed and traded on the stock exchange). In general, the tax exemption of REITs aims to give equal rights to less affluent investors, who need to use institutional intermediaries, compared to those more affluent investors, who would be able invest directly in real estate. Direct investment in the real estate market does not entail any indirect tax burden, while the use of institutional investment intermediation services makes it necessary to accept the costs due to the tax burden imposed on the intermediary. The idea of evening out the rights of both groups of investors is based on the concept of tax integration, which has found practical application in REITs. Tax integration makes it possible to minimize, and in some cases eliminate, the distortions in investment decisions [Davies 1986, p. 133-136, Integration... 1992, p. 12]. REIT as a tax transparent entity not only ensures the transfer of benefits to investors, but can also increase them. The privilege of no taxation at the organizational level of the REIT eliminates the tax shield and determines the financial management strategy. This strategy is not based on costs, as there is no need to generate them in order to lower the tax base [Feng et al. 2007, passim, Giambona et al. 2008, p. 117]. Tax integration results in rational cost management, which are usually high anyway due to real estate property being a tangible asset.

In most European countries that have implemented the REIT model by incorporating its legal regime, the aim was to improve the quality and competitiveness of investment intermediation in the real estate market. In order to achieve this goal, it is necessary to accurately identify local conditions conducive to effective implementation. As a rule, the REIT regime is intended as a universal, tax-transparent investment intermediary, mainly to transfer the benefits of real estate investments to investors themselves. To ensure that this is happening, it must be firmly embedded in legal regulations concerning not only the financial market and the real estate market, but also the tax system. Specific local conditions (especially local legal regulations of the real estate market and the tax system) will affect the detailed regulations of the implemented REIT regime, and their inclusion will determine the competitiveness and effectiveness of the REIT.

\section{Premises and basic principles for establishing FINN in Poland}

As a consequence of the failure, so far, to implement the legislation of the Polish equivalent of REITs, the domination of such foreign entities in Poland is apparent. The commercial real estate market in particular has become an area of investment expansion for REITs registered in other European Union countries. By taking advantage of the preferences granted by the legislation in their home countries, primarily related to the special tax status, foreign REITs can achieve a competitive advantage over domestic entities that do not enjoy such preferences. The introduction of FINN to the Polish legal system, as an institution similar to European REITs, should eliminate the evident 
disproportion in relation to the status of domestic entities, starting by giving them an additional privileged position on the residential real estate market, where foreign REITs cannot operate.

The second goal of the draft act on FINN is to stimulate and gradually develop the market of real estate properties (first residential, in the also future commercial) for lease or rent, by involving retail investors, for whom the only option so far has been to invest capital in real estate investment funds. By increasing the attractiveness of undertaking and conducting investment activities in the market of housing for rent, i.e. the creation of new or transformation of already operating entities on the real estate market into FINN, an alternative to investing by retail investors will be provided. Referring to the genesis of REIT, discussed in section 2, FINNs' activity is to make the real estate market accessible to small retail investors who so far perceived these investment opportunities as inaccessible to them due to high-cost.

The proposed legislation regulating the functioning of FINN in Poland largely corresponds to Western European standards, particularly with regard to the fundamental principles of REITs [projected Act on FINN 2018]. It is assumed that the tax-privileged FINN status will be granted to a public joint stock company with its registered office or management board in the territory of the Republic of Poland, whose shares have been admitted to official trading and listed in the stock market. This status is verified by the Polish Financial Supervision Authority, which, after receiving a positive opinion, enters FINN into the register.

FINN is a passive investment broker because its primary purpose is to regularly pay dividends to shareholders out of the profit derived from rental or lease income. FINN is obliged to pay an annual dividend at the level not lower than $90 \%$ of the profit for the previous financial year, which may be:

- increased by undistributed profits from previous years and the amounts transferred from the supplementary capital and reserve capitals created from profit, which may be allocated to the payment of dividends, and

- reduced by uncovered losses, own shares, and amounts which, according to other regulations or the articles of association, should be allocated from the profit for the last financial year to supplementary capital or reserve capital.

In order to eliminate interpretation doubts or ambiguities, a definition of the concept of real estate was introduced for the purposes of the Act on FINN. It differs from the definition applicable under civil law, because real estate means buildings permanently attached to the land or parts of such buildings, provided that under special regulations they constitute an object of ownership separate from the land.

Within this scope, the following activities of FINN are possible:

- rental/lease of real estate or parts thereof,

- sale of real estate or parts thereof against payment,

- financial activities in the field of managing shares or stocks in other companies (subsidiaries). 
In order to prevent FINNs from investing outside the real estate market with the use of subsidiaries, the status of the latter has also been regulated by law. A subsidiary of FINN may be a joint-stock company, a limited liability company, or a limited jointstock company with its registered office or management board in the territory of the Republic of Poland, the share capital of which must be owned by FINN in no less than 95\%, and which additionally meets the following conditions:

- real estate constitutes no less than $80 \%$ of the balance sheet value of assets,

- no less than $90 \%$ of net sales revenues comes from the lease of real estate or its part, or the sale of rental real estate or a part thereof for at least one year,

- the carrying amount of credit or loan obligations does not exceed $50 \%$ of the carrying amount of assets,

- annually, a dividend is paid at a level not lower than $90 \%$ of the profit for the last financial year:

- increased by undistributed profits from previous years and by amounts transferred from the supplementary and reserve capitals created from profit, which may be allocated for the payment of dividends,

- as well as reduced by uncovered losses, own shares and amounts which, according to other regulations or the articles of association, should be allocated from the profit for the last financial year to supplementary capital or reserve capital.

The FINN's by-laws also define the principles of the investment policy of the company or its subsidiaries, in particular the type of real estate being the subject of the investment - namely, these may only be residential real estate. There is also a requirement that income from the rental of real estate or parts thereof is to be obtained by FINN from the rental of at least three real estate properties or parts thereof. The purpose of this provision is to guarantee an appropriate diversification of FINN's real estate portfolio, and this condition should be considered as fulfilled also at the level of a group of companies.

The last and most important issue is how to implement the principle of tax integration in the draft Act on FINN. Tax-favourable conditions for reinvestment would consist in:

- deferment of the tax obligation of the income obtained by FINN from the rental or sale of real estate or a part thereof - until its equivalent is spent on:

- the payment of dividends to investors (shareholders),

- the payment of remuneration to persons who are members of the management, supervisory and control bodies of such a company, and persons representing the company or these bodies for their functions.

- complete exemption from taxation with income tax, of the income obtained by subsidiaries of FINN from the rental or sale of real estate or a part thereof.

The draft also includes the principles of taxation of the income from capital investments, which are attractive to FINN shareholders. In particular, the income obtained by these investors from participation in FINN's profits (dividends, dividend advances) 
would be exempt from income tax. This exemption would apply to both CIT and PIT taxpayers.

\section{The real estate companies sector as a functional base for FINN}

The successful incorporation of the regulations governing the operation of FINNs and the subsequent implementation of the new entity on the market will be ensured by taking into account the local legislative framework and system conditions. The projected new law tries to assimilate the new regulations as much as possible with the existing ones, but the introduction of FINNs into the legal and tax system will be a significant institutional change that will arouse both applause and open reluctance by market participants - depending on whether it is to their benefit, or not. The favourable tax status of FINN will not remain indifferent to its current competitors, which are joint-stock companies listed on the Warsaw Stock Exchange and included in the WIG-Nieruchomości Index, or real estate investment funds. For these entities, the planned institutional change will be a huge challenge and a factor determining the strategy for their further action. A similar situation occurred in 2007, when the G-REIT regime was introduced in Germany, and the UK-REIT regime was introduced in Great Britain. In Great Britain, in the first two years since the new law had been passed, most of the UK-REITs were created as a result of transformations of the existing joint stock companies investing in the real estate market, which then focused on investing in commercial real estate, with almost no involvement in residential real estate [Westbrooke and Marvin 2010, p. 14]. A similar course of events took place in Germany, where the first G-REITs also appeared on the market as a result of the transformation of joint-stock companies, and the statutory inability to invest in residential real estate forced G-REIT to operate on the commercial real estate market [Schweizer et al. 2013, p. 71].

It is likely that the development of events on the Polish market will be similar to those in Germany and Great Britain, after the entry into force of the Act on FINN. The main entities interested in obtaining the FINN status will be public joint-stock companies that already had invested capital in the residential real estate market, while implementing development projects. The second group, i.e. real estate investment funds, will not show interest in changing their current status, because they apply the format of closed-ended funds with long-term investment strategies and they lack experience in the public market, where maintaining short-term liquidity is the main challenge.

Thus, public joint-stock companies listed on the Warsaw Stock Exchange and included in the WIG-Nieruchomości index were qualified for the analysis of the development potential of FINN as a new sector of the capital market. All companies were qualified, which should be treated as a preliminary analysis of the subjective base for the development of the FINN market. This is due to the fact that the pilot survey, which had been conducted, merely allowed obtaining the information that the managers of the analysed entities are no more than looking favourably upon the proposed legislative solutions. At the stage when only the draft Act on FINN is known, and there remains 
uncertainty as to the final shape of the legal regime, none of the companies is willing to take any action in this regard.

Therefore, the assumption was made that the prospect of an increase in the WIG-Nieruchomości index, i.e. the development of the real estate sector, will create a positive climate for making decisions on the possible transformation of companies from this index into FINN by mid-2021, by which time the provisions of the FINN Act should already apply. The multiple regression model was applied in order to forecast the volatility of the WIG-Nieruchomości index, where only time was used as the explanatory variable at this stage. Figure 1 shows a model with a 10 -year data time series, starting from April 2007, as the basis for the forecast. This covers a period of an already-ending boom in the real estate market followed by a market crash, with the spectacular bankruptcy of Lehmann Brothers in the background. The time series made it possible to determine the market growth forecast until mid-2021, by which time the statutory structure of the FINN should be known. However, the high amplitude of the index value fluctuations in the period 2007-2010 resulted in the poor fit of the model, which is reflected in the low value of $\mathrm{R}^{2}=0.6463$. This prompted a further search for a greater match.

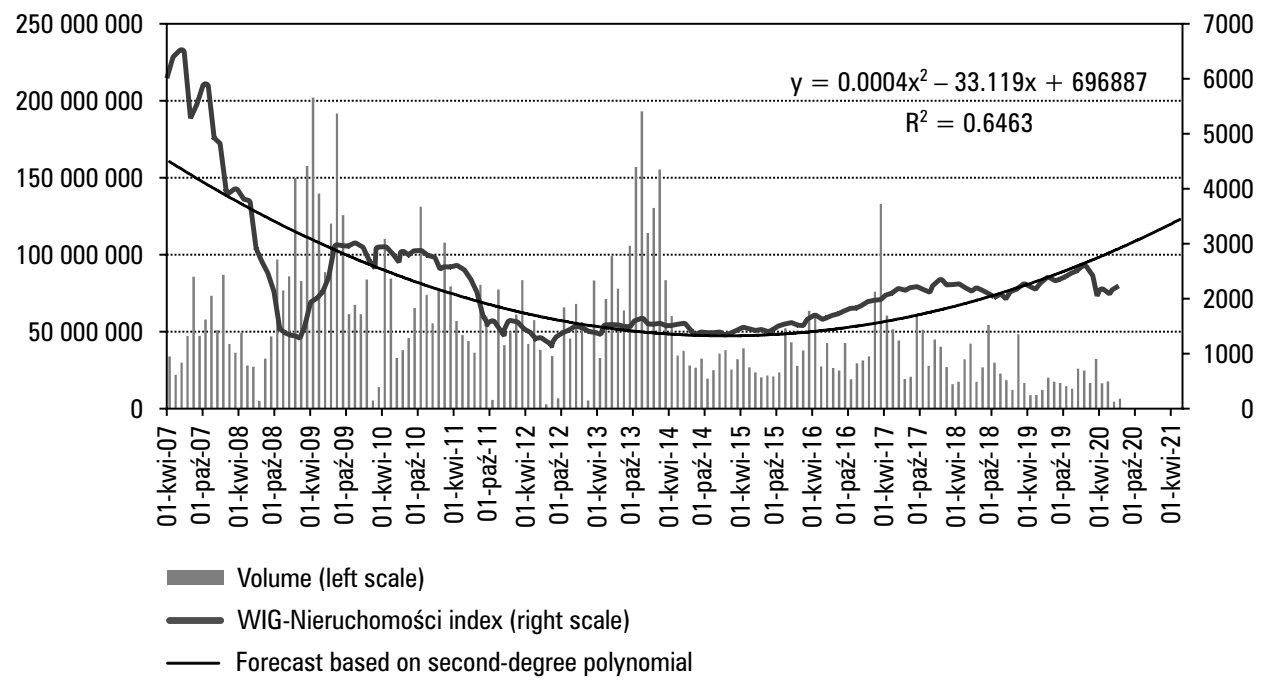

Source: Author's own study based on data from https://stooq.pl (accessed: 12 July 2020)

Fig. 1. WIG-Nieruchomości index - forecast using the multiple regression model (second degree polynomial) based on a 13-year time series

In the next stage of forecasting, an 8-year time series was used, after eliminating the periods of the recession in the previous data set: subprime mortgage crisis in the United States and public finance crisis in Europe in 2009-2011. The value of the WIG-Nieruchomości index from 2012 to the first quarter of 2020, i.e. in the period of 
no crisis events, allowed for the construction of a forecast model with a much better fit, where $\mathrm{R}^{2}=0.8979$ (Fig. 2). The forecast carried out at this stage signals an even stronger growth of the index in the given perspective, which, according to the adopted assumptions, should be interpreted as a favourable climate for making decisions about the transformation of real estate joint-stock companies listed on the Warsaw Stock Exchange into FINN companies.

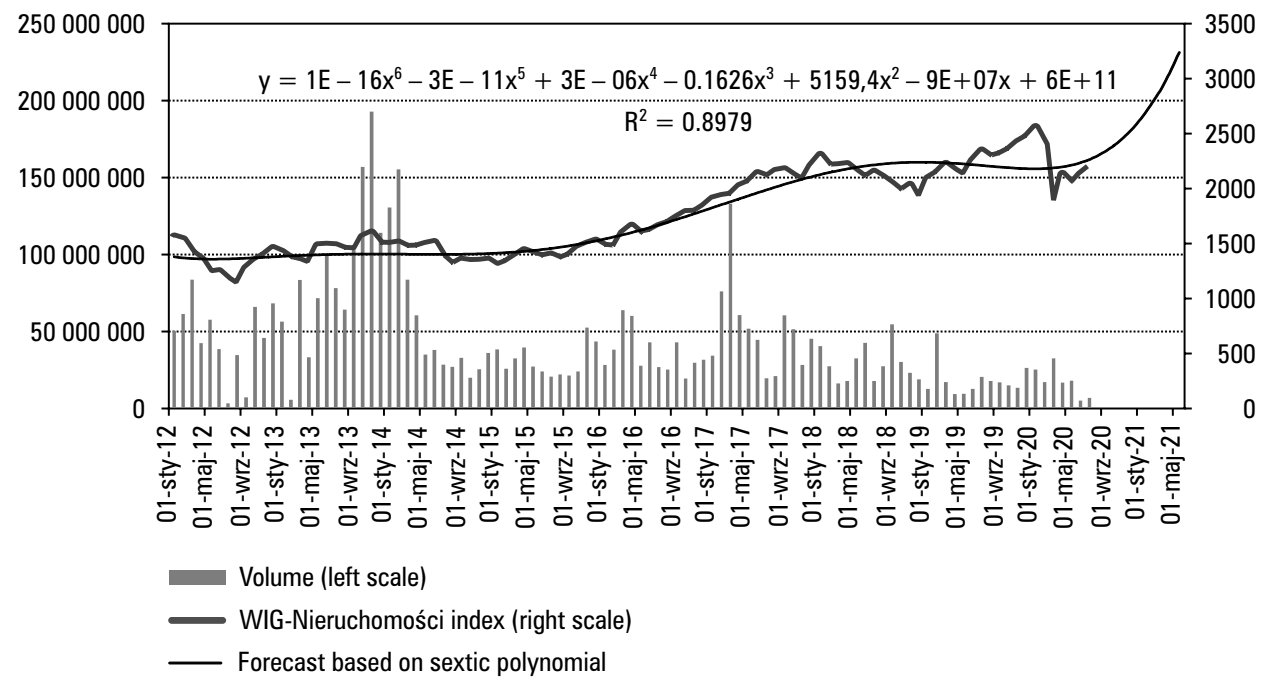

Source: Author's own study based on data from https://stooq.pl (accessed: 12 July 2020)

Fig. 2. WIG-Nieruchomości index - forecast applying a multiple regression model (sextic polynomial) based on an 8-year time series

\section{Conclusion}

The introduction of FINN to the Polish financial system opens a perspective for a real institutional change, taking place both on the financial market, and the real estate market in Poland. According to the premises of D.C. North, this was initiated by the competition, especially on the part of foreign entities investing in the commercial real estate market. In the light of the assumptions of the New Institutional Economy, this external stimulus will contribute to the creation of a new organization - the FINN, which will perform the functions of a passive investment intermediary on the financial real estate market. This activity will be modelled on the type of tax-privileged entity known elsewhere in the world and recognized under the name REIT. The positive dimension of the expected institutional change will be influenced by many factors, both global and local. In the first phase of building the FINN market, the macroeconomic situation in Poland will be important, reflected in the trend on the stock 
exchange. In the conditions of index growth, there is a favourable climate for taking up the strategic challenge, which will be expressed in the decision of the management of companies from the WIG-Nieruchomości index to transform and submit to the restrictions of the FINN legal regime in exchange for tax privileges. The increased values in the WIG-Nieruchomości index forecast for mid-2021 lead us to believe that this will contribute to the initiation of the FINN market as a new segment of the capital market in Poland.

\section{References}

Baum A. 2015. Real Estate Investment: A Strategic Approach. Routlege.

Davies D.G. 1986. United States Taxes and Tax Policy. Cambridge University Press, New York.

Feng Z., Ghosh Ch., Sirmans C.F. 2007. On the Capital Structure of Real Estate Investment Trusts. Journal of Real Estate, Finance and Economics, 34, 1.

Giambona E., Harding J.P., Sirmans C.F. 2008. Explaining the Variation in REIT Capital Structure: The Role of Asset Liquidation Value. Real Estate Economics, Spring, 36, 1.

Integration of the Individual and Corporate Tax Systems. Taxing Business Income Once. 1992. Report of The Department of the Treasury, Washington, January.

North D.C. 1990. Institutions, Institutional Change and Economic Performance. The Cambridge University Press.

North D.C. 1993. Five Propositions about Institutional Change. http://econwpa.repec.org/eps/ eh/papers/9309/9309001.pdf

Projekt ustawy o firmach inwestujących w najem nieruchomości. 2018. http://www.sejm.gov.pl/ sejm8.nsf/druk.xsp?nr=2855

Schweizer D., Hass L.H., Johanning L., Rudolph B. 2013. Do Alternative Real Estate Vehicles Add Value to REIT's? Evidence from German Open-ended Property Funds. Journal of Real Estate Finance and Economics, July, 47.

Sjostrand S.-E. 2016. Institutional Change: Theory and Empirical Findings. Routledge.

Westbrooke N., Marvin D. 2010. REITs in the UK - in the doldrums. EPRA Global REIT Survey - Supplement, September.

Dr Renata Papież

Katedra Finansów i Polityki Finansowej

Uniwersytet Ekonomiczny w Krakowie

ul. Rakowicka 27, 31-510 Kraków

ORCID: 0000-0002-0239-4512

e-mail: renata.papiez@uek.krakow.pl 